\title{
Screening of Rhizobacteria for Biological Control of Cucumber Root and Crown Rot Caused by Phytophthora drechsleri
}

\author{
Mojdeh Maleki $^{1 *}$, Lachin Mokhtarnejad ${ }^{2}$ and Somayyeh Mostafaee ${ }^{1}$ \\ ${ }^{1}$ Department of plant protection, Islamic Azad University of Varamin-Pishva, Varamin, Iran \\ ${ }^{2}$ Department of plant protection, University of Tehran, Iran \\ (Received on November 5, 2010; Accepted on February 12, 2011)
}

\begin{abstract}
Antagonistic rhizobacteria, more specifically fluorescent pseudomonads and certain species of Bacillus, are known as biocontrol agents of fungal root diseases of agronomic crops. In this study, 144 bacteria were isolated from cucumber rhizosphere and screened as potential biological control agents against Phytophthora drechsleri, the causal agent of cucumber root rot, in vitro condition. Non-volatile compounds of $\mathbf{2 3}$ isolates showed noticeable inhibition zone $(>30 \%)$ against $P$. drechsleri, whereas volatile compounds of 7 isolates could prevent more than $30 \%$ of the mycelial growth of the fungus. All promising isolates, except of Pseudomonas flourescens V69, promoted significantly plant growth under in vitro condition. P. flourescens CV69 and V11 exhibited the highest colonization on the root. Results of the greenhouse studies showed that a reduction in disease incidence by use of some strains, and particularly use of strains CV6 and V11 as a soil treatment, exhibited a reduction in disease incidence so that suppressed disease by 85.71 and $69.39 \%$ respectively. Pseudomonas flourescens CV6 significantly suppressed disease in comparison to Ridomil fungicide. The use of mixture bacterial strains in the soil inoculated by the fungus resulting in falling down the most of the plants which didn't show significant difference with infected control soils without bacteria.
\end{abstract}

Keywords : biological control, cucumber, Phytophthora drechsleri, rhizobacteria, root rot

Phytophtora blight, root and crown rot of cucumber is one of the most destructive pathogens of cucumber in entire the world (Erwin and Ribeiro, 1996; McGrath, 2001; Ristaino and Johnston, 1999). Phytophthora capsici Leonian usually reported as major agent of this disease (Babadoost and Islam, 2003) whereas $P$. drechsleri reported as a major agent of that in Iran (Alavi and Strange, 1979). On cucumber, these pathogens causes damping-off, crown and root rot, stem lesions, foliar blight, and fruit rot (Alavi and Strange,

\footnotetext{
*Corresponding author.

Phone)+98-291-4220650, FAX) +98-291-4224990

E-mail)mojdehmaleki@iauvaramin.ac.ir
}

1982; Kreutzer et al., 1940; McGrath, 2001). This pathogen infects susceptible hosts throughout the growing season and survives as dormant oospores during the winter (Lamour, and Hausbeck, 2001). Cucumber varieties resistant to Phytophthora disease are not available to our knowledge. Some practices such as planting on raised beds, management of field moisture, straw mulching, planting tolerant cultivars, and application of some fungicides may reduce severity of Phytophthora diseases on vegetables (Hwang and Kim, 1995). So, this disease is very difficult to control and no single method is available (Hwang and Kim, 1995; Ristaino and Johnston, 1999). Moreover, resistance to the systemic fungicides developed rapidly in Phytophthora after its application in the field (Lamour, and Hausbeck, 2000; Lamour and Hausbeck, 2001). Recently, soilborne diseases have been controlled by means of certain beneficial bacteria that are indigenous to the rhizosphere of plants (Thomshaw, 1996) and known as plant growth promoting rhizobacteria (PGPR) (Kloepper et al., 1980). Bacterial isolates of Actinomycetes, Streptomyces spp., Flavobacterium sp., Pseudomonas flourescens and Bacillus spp. have been reported to control of Phytophthora disease of plants (Alexander, 1999; Kun et al. 2002; 1984; Osburn et al., 1995; Tracey et al., 2004; Sid Ahmed et al., 2003). PGPR are known to rapidly colonize the rhizosphere (Rangajaran et al., 2003), produce secondary metabolites such as antibiotics and phytohormones (Keel et al., 1992), and can also be beneficial to the plant by stimulating growth of plants (Bloemberg and Lugtenberg, 2001).

Currently there is very limited knowledge regarding the biological suppression of Phytophthora root and crown rot in cucumber by application of PGPR. The aim of this study is therefore to isolate bacteria from the cucumber rhizosphere and screen them against $P$. drechsleri, one of the major causes of root and crown rot in Iran. This study may contribute to the introduction of PGPR systems in biological control of soil-born phytopathogenic fungi in cucumber from Iran. 


\section{Material and Methods}

Pathogen isolate and preparation of inoculum. Phytophtora drechsleri strain CP4, isolated from cucumber, Pishva region, Varamin, was received from Iranian Research Institute of Plant Protection, Evin, Tehran, and was stored on agar in sterile distilled water (SDW) in the dark at $5-7^{\circ} \mathrm{C}$. For inoculums preparation, $100 \mathrm{~g}$ of white bean seed add to 250 $\mathrm{ml}$ of water in a $500 \mathrm{ml}$ Erlenmeyer flask and then autoclaved for $20 \mathrm{~min}$ at $121^{\circ} \mathrm{C}$ in two successive days. The flask was inoculated with a mycelial plug from a 7-day-old culture of $P$. drechsleri, incubated 3 weeks at $26^{\circ} \mathrm{C}$, and shaken daily to break up particles. This inoculum ground in a mill and used for greenhouse studies.

Field sampling and isolation of bacteria. In April 2009, a total of 50 cucumber plants were collected from fields and greenhouses of Varamin, Tehran province, Iran. Roots gently removed from soil and placed in plastic bags before they were transported to the laboratory. Adhering soil was carefully brushed off the plant roots, followed by gentle washing of the roots in sterile water. One gram of roots was added in $9 \mathrm{ml}$ of $0.1 \mathrm{M}$ phosphate buffer ( $\mathrm{pH} 7.0$ ) supplemented with $0.025 \%$ Tween 20 and serially diluted. Then the tubes were vortexed for $5 \mathrm{~min}$. Then, $100 \mu \mathrm{l}$ of dilutions $10^{-1}$ to $10^{-4}$ was plated on Nutrient Agar (NA) or Gould's $\mathrm{S} 1$ medium $18 \mathrm{~g}$ of agar, $10 \mathrm{~g}$ of sucrose, $10 \mathrm{ml}$ of glycerol, $5.0 \mathrm{~g}$ of Casamino Acids (Difco), $1.0 \mathrm{~g}$ of $\mathrm{NaHCO}_{3}, 1.0 \mathrm{~g}$ of $\mathrm{MgSO}_{4} \cdot 7 \mathrm{H}_{2} \mathrm{O}, 2.3 \mathrm{~g}$ of $\mathrm{K}_{2} \mathrm{HPO}_{4}, 1.2 \mathrm{~g}$ of sodium lauroyl sarcosine (SLS), and $20 \mathrm{mg}$ of trimethoprim. NA medium was used as a common medium to isolation of both gram positive and gram negative bacteria. S1 medium is a selective medium for isolation of fluorescent pseudomonad's (Gould et al., 1985).

In vitro antagonistic activity. Inhibition of mycelial growth of $P$. drechsleri by non-volatile compounds of the bacterial isolates was tested by using the dual culture technique as described by Ahmed Idris et al. (2007). Three $20 \mu 1$ drops from the $10^{8} \mathrm{cfu} / \mathrm{ml}$ suspension were equidistantly placed on the margins of potato dextrose agar (PDA) plates and incubated at $28^{\circ} \mathrm{C}$ for $24 \mathrm{~h}$. A $6 \mathrm{~mm}$ agar disc from fresh cultures of $P$. drechsleri was placed at the centre of the PDA plate for each bacterial isolate and incubated at $27 \pm 1{ }^{\circ} \mathrm{C}$ for seven days. The radii of the fungal colony towards and away from the bacterial colony were measured. The percentage growth inhibition was calculated using the following formula:

$$
\% \text { Inhibition }=\frac{(\mathrm{R}-\mathrm{r})}{\mathrm{R}} \times 100
$$

Where, $r$ is the radius of the fungal colony opposite the bacterial colony and, $\mathrm{R}$ is the maximum radius of the fungal colony away from the bacterial colony (control without bacterial colony).

Volatile compounds produced by bacteria were detected in a split plate experiment (Kraus and loper, 1992). Bacteria were grown for 3 days on tryptic soy agar (TSA; Difco) in one side of a split plate before inoculation of the PDA in the other side with a 6-mm-diamcter plug of PDA culture of $P$. drechsleri. Radial growth of $P$. drechsleri on the fungal side was measured after 5 day of incubation at $27^{\circ} \mathrm{C}$ and the percentage of growth inhibition was calculated. Promising isolates were identified as an above technique.

Identification and characterization of antagonistic bacteria. The bacteriological characteristics (Gram staining, growth on media, catalase reactions and hypersensitivity reactions on tobacco) were carried out as described by Schaad et al. (2001).

The determination of physiological characteristics of antagonistic bacteria was performed as described by Schaad et al. (2001).

Plant growth promotion and root colonization. Isolates which showed antagonistic activity in the dual culture assays, were tested for their ability to promotion of plant growth and root colonization. Surface sterilized $(2.5 \%$ $\mathrm{NaOCl}, 5 \mathrm{~min}$ ) cucumber seeds of Soltan cultivar were pregerminated in moist chambers at $22^{\circ} \mathrm{C}$ for $36 \mathrm{~h}$. Sterility of seeds was proved by a print on nutrient agar. Bacteria were grown on NB for $16 \mathrm{~h}$ and then centrifuged and resuspend in physiological salt solution $(0.85 \%)$. At the next stage, standard 24-well microplates were filled with 1 $\mathrm{ml}$ of water agar $(1.2 \%, \mathrm{pH} 6.8)$. In each well, one seed was placed on the agar surface and inoculated with $20 \mu 1$ of bacterial suspension $\left(10^{5} \mathrm{cfu}\right.$ per $\mathrm{ml}$ physiological salt solution $(0.85 \%)$. Inoculated microplates were transferred to a phytochamber for two weeks $\left(22 / 16^{\circ} \mathrm{C}, 16 / 8 \mathrm{~h}\right.$ day/night, and artificial light) and the length and dry weight of stems and roots were measured to determine the effects of bacterial treatments on plant growth. Moreover one gram of root from each treatment was aseptically excised and placed in $25-\mathrm{ml}$ flasks containing $5 \mathrm{ml}$ of sterile $0.85 \% \mathrm{NaCl}$, and vigorously shaken at $300 \mathrm{rpm}$ for $30 \mathrm{~min}$. The resulting suspensions were serially diluted and plated on NA, then incubated at $28^{\circ} \mathrm{C}$ for colony counts. The level of root colonizing- acteria was calculated as colony forming units/ $\mathrm{g}$ root (cfu/g root).

Preparation of pathogen inoculum and greenhouse studies. The ability of isolates to suppress cucumber Phytophthora damping-off was examined on Cucumis sativus $\mathrm{L}$. Soltan cultivar. Seven surface sterilized $(2.5 \% \mathrm{NaOCl}, 3$ 
min) seeds of Soltan cultivar seeded in polyethylene pots ( 8 $\mathrm{cm}$ in diameter) filled with a 1:1:2 mixture of peat, sand and soil from Varamin region, Iran. Then, the pots were transferred to the greenhouse $\left(16 \mathrm{~h}\right.$ of light and $\left.25-27^{\circ} \mathrm{C}\right)$ watered at a three-day interval and kept for 10 days. Ten days after seeding, pots were inoculated with $30 \mathrm{~g}$ of the potting mix that had been blended with white bean seed inoculum of $P$. drechsleri and drenched with $20 \mathrm{ml}$ of bacterial suspensions $\left(10^{6}\right.$ cells mll $\left.{ }^{-1}\right)$ or a solution of $1 \mathrm{~g} \mathrm{~L}^{-1}$ Ridomil MZ-72 (Metalaxyl + Mancozeb $=8+64 \%$ WP). Then the pots watered and arranged in a randomized complete block design and incubated in condition mentioned above. The treatments in this experiment were: Pots inoculation with $P$. drechsleri and each of bacterial strains inoculation with $P$. drechsleri and mix of bacterial strains, inoculation with $P$. drechsleri and Ridomil, inoculation only with $P$. drechsleri but no bacteria $(\mathrm{CI})$ and control without microbial inoculation $(\mathrm{C})$.

After 2 and 3 weeks, percentage of the healthy plants was determined. After last assessment of disease severity, fresh and dry weight parameters of the plants were measured.

Statistical analysis. In vitro and greenhouse experiments were repeated three times in a completely randomized esign and randomized complete block design, respectively. The individual plant in the pot was the experimental unit. Statistical analyses were carried out using the software package SAS (V. 9.1). A mean comparison was performed using the Duncan's multiple range test. Correlations between volatile and non-volatile antifungal activities and root colonization ability with disease suppression were done by using the software SPSS (V. 10.1).

\section{Results}

Isolation and screening of antagonistic isolates. According to the Table 1, among of the 144 bacterial isolates, 23 isolates exhibited a more than $30 \%$ inhibition of mycelia growth of $P$. drechsleri by non-volatile inhibitors. The maximum inhibition achieved by isolate CV3 (55.56\%). Inhibition of mycelial growth by non-volatile compounds of isolates CV6, V11, V14, V69, V127 and CV12 determined by 45.56, 43.33, 43.33, 42.53, 42.3 and 42.23 percent, respectively. Furthermore, volatile metabolites of seven isolates CV6, V16, V28, V81, V28, and V64 inhibited the mycelial growth of $P$. drechsleri considerably (Table

Table 1. Inhibition of Phythophtora drechsleri mycelial growth on potato dextrose agar by rhizobacterial isolates

\begin{tabular}{|c|c|c|c|c|c|}
\hline \multirow{2}{*}{ Bacterial isolates } & \multicolumn{2}{|c|}{ Mycelial inhibition (\%)* } & \multirow{2}{*}{ Bacterial isolates } & \multicolumn{2}{|c|}{ Mycelial inhibition (\%) } \\
\hline & Non-volatile & Volatile & & Non-volatile & Volatile \\
\hline $\mathrm{CV} 3$ & $55.56 * \mathrm{a}^{* *}$ & $21.66 \mathrm{ef}$ & V10 & 31.1ikjl & $15.33 \mathrm{ij}$ \\
\hline CV6 & $45.56 b$ & $32.33 b$ & V42 & 30kjlm & 22.06ef \\
\hline V11 & $43.33 b c$ & $22.66 \mathrm{de}$ & V41 & $29.8 \mathrm{klmn}$ & $4 q$ \\
\hline V14 & $43.33 b c$ & 13jkl & V81 & $29.1 \mathrm{klmn}$ & $38 \mathrm{a}$ \\
\hline V69 & $42.53 b c$ & $39.3 \mathrm{a}$ & V38 & $29 \mathrm{klmn}$ & 17hi \\
\hline V127 & $42.3 b c$ & $12 \mathrm{klm}$ & $\mathrm{V} 2$ & $27.761 \mathrm{mno}$ & 18ghi \\
\hline CV12 & $42.23 b c$ & $22 \mathrm{ef}$ & V17 & 27.61mno & $27 \mathrm{c}$ \\
\hline V28 & $41 \mathrm{~cd}$ & $33.33 b$ & V79 & 26.66mnop & $13.66 \mathrm{jk} 1$ \\
\hline V51 & $40.7 \mathrm{~cd}$ & $11 \mathrm{lmn}$ & V49 & 25.56 nop & 17hi \\
\hline V30 & $40.3 \mathrm{~cd}$ & $6 \mathrm{pq}$ & $\mathrm{V} 3$ & 24.43opq & $11.8 \mathrm{klm}$ \\
\hline CV8 & $40 \mathrm{~cd}$ & 8.66no & V55 & $24.47 \mathrm{opq}$ & 17.1hi \\
\hline V27 & 38.9 cde & $13.3 \mathrm{jkl}$ & $\mathrm{V} 1$ & $23.33 p q$ & 17.03hi \\
\hline V13 & $37.76 \mathrm{efd}$ & $18.5 \mathrm{gh}$ & V37 & $21.19 \mathrm{qr}$ & 23.06de \\
\hline V26 & 36.66efdg & $22 \mathrm{ef}$ & V62 & $21.16 q \mathrm{q}$ & $15.36 \mathrm{ij}$ \\
\hline V12 & 36.60efdgf & $10 \mathrm{mno}$ & V21 & $21.14 \mathrm{qr}$ & $19.83 \mathrm{fg}$ \\
\hline V46 & 35.56efgh & 9no & V61 & $21.1 \mathrm{qr}$ & $13.86 \mathrm{jk}$ \\
\hline V54 & 34.43fghi & 23.1de & V66 & $18.97 \mathrm{r}$ & $24.78 \mathrm{dc}$ \\
\hline V71 & 34.43fghi & $13.66 \mathrm{jkl}$ & V47 & $18.9 \mathrm{r}$ & 8op \\
\hline V15 & 15hi & $17.9 \mathrm{~h}$ & V64 & $18 \mathrm{r}$ & $34.33 b$ \\
\hline V25 & $32.23 \mathrm{hijk}$ & $27 \mathrm{c}$ & $\mathrm{C}$ & $0 \mathrm{~s}$ & or \\
\hline V16 & 31.8ikjl & $37.66 \mathrm{a}$ & & & \\
\hline
\end{tabular}

*Mycelial inhibition (\%) was calculated as $(\mathrm{R}-\mathrm{r}) / \mathrm{R} \times 100$, where $\mathrm{R}$ is mycelial growth away from the bacterial colony (the maximum growth of the fungal mycelia), $r$ is mycelial growth towards the bacteria.

$* *$ Values followed by the same letter were not significantly different at $5 \%$, as determined by variance analysis followed by Duncan's test. 
Table 2. In vitro growth promotion and root colonization of cucumber plants by rhizobacterial strains

\begin{tabular}{lcccc}
\hline \hline & \multicolumn{4}{c}{ PGPR } \\
\cline { 2 - 5 } Bacterial isolate & $\begin{array}{c}\text { Stem } \\
\text { length }\end{array}$ & $\begin{array}{c}\text { Root } \\
\text { length }\end{array}$ & $\begin{array}{c}\text { Foliage } \\
\text { weight }\end{array}$ & $\begin{array}{c}\text { Root } \\
\text { weight }\end{array}$ \\
\hline B. subtilis V14 & $12.96 \mathrm{a}$ & $9.5 \mathrm{a}$ & $4.83 \mathrm{a}$ & $4.39 \mathrm{a}$ \\
P. aeruginosa CV3 & $9.46 \mathrm{bc} *$ & $7.5 \mathrm{~b}$ & $3.28 \mathrm{bc}$ & $2.6 \mathrm{~cd}$ \\
P. fluorescens CV6 & $12.23 \mathrm{a}$ & $9.4 \mathrm{a}$ & $4.76 \mathrm{a}$ & $3.87 \mathrm{ab}$ \\
P. fluorescens V11 & $9.26 \mathrm{c}$ & $7 \mathrm{~b}$ & $3.95 \mathrm{ab}$ & $3.58 \mathrm{abc}$ \\
P. fluorescens V16 & 11.76 & $9.26 \mathrm{a}$ & $4 \mathrm{ab}$ & $3.58 \mathrm{abc}$ \\
P. fluorescens V69 & $6.56 \mathrm{~d}$ & 5.66 & $2.6 \mathrm{~cd}$ & $1.53 \mathrm{e}$ \\
P. putida V28 & $12.53 \mathrm{a}$ & $7.93 \mathrm{~b}$ & $4.05 \mathrm{ab}$ & $3.02 \mathrm{bc}$ \\
P. putida V64 & $10.46 \mathrm{bc}$ & $7.56 \mathrm{~b}$ & $4.35 \mathrm{a}$ & $3.02 \mathrm{bc}$ \\
Control & $7.03 \mathrm{~d}$ & $5.56 \mathrm{c}$ & $1.86 \mathrm{~d}$ & $1.7 \mathrm{de}$ \\
\hline
\end{tabular}

*Values followed by the same letter were not significantly different at $5 \%$, as determined by variance analysis followed by Duncan's test.

1), so that the maximum inhibition achieved by any isolate was $39.33 \%$ (V69).

Identification and characterization of antagonistic bacteria. According to morphology, physiological and biochemical characteristics of promising isolates, isolates CV6, V11, V16 and V69 identified as Pseudomonas flourescens. Isolates V28 and V64 got best matches with $P$. putida. Isolates CV3 and V14 were closely match to $P$. aeruginosa and Bacillus subtilis, respectively (data not shown).

Plant growth promotion and root colonization in phytochamber. The effect of bacterial isolates on the growth of cucumber seedlings was monitored by measuring of length and dry weight of the roots and stems (Table 2). All strains except of $P$. fluorescens V69 promoted significantly plant growth in comparision to nontreated control. Strains CV6, V14 and V28 caused to increase the length of stem and root, considerably. In addition, Strains CV6, V14 and V64 showed the most effect on enhancing the foliar weight of cucumber seedling. However, both strains, CV6 and V14, exhibited the greatest effect to enhance root weight of seedling.

Study of root colonization in vitro demonstrated that some of the strains have more ability to root colonization than others. The population density on roots of plants treated with CV6 and V11 reached to 8.03 and $7.76 \log _{10}$ CFU g ${ }^{-1}$ root respectively (Fig. 1). Strains V69 and V64 were not effective root- colonizers as their cell count was less than $5 \log _{10} \mathrm{CFU} \mathrm{g} \mathrm{g}^{-1}$ root. It seems there is a correlation between root colonization talent of selected strains and their growth promoting ability, as in the most cases the strains with a highefficacy of root colonization resulted in increasing growth of plants (Table 2, Fig. 1).

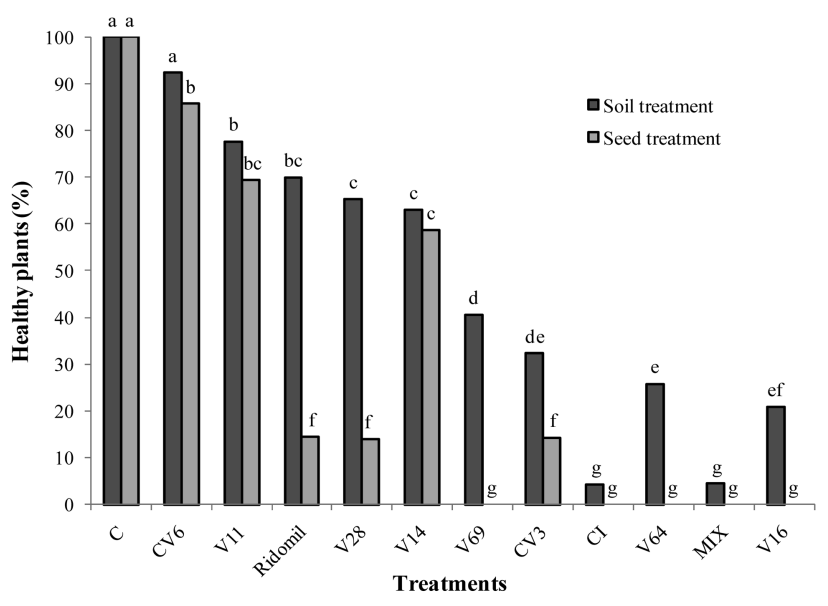

Fig. 1. Colonization levels of eight bacterial biocontrol strains on the roots of the cucumber cultivar Soltan (in $\log \mathrm{CFU} / \mathrm{g}$ of root mass).

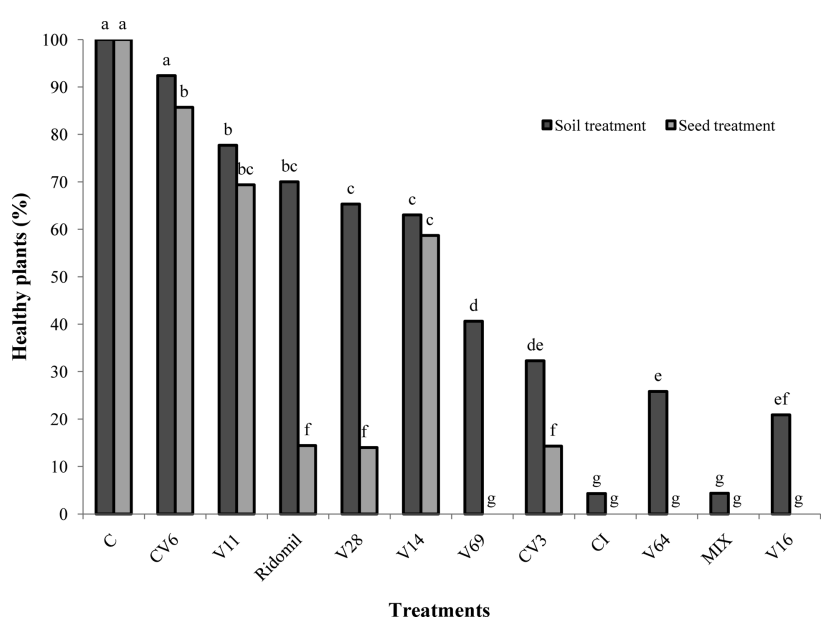

Fig. 2. Suppression of Phytophthora root rot by selected strains in greenhouse. Isolates was applied as soil and seed treatments, percent of healthy plants was determined after 3 weeks. Values followed by the same letter were not significantly different at $5 \%$, as determined by variance analysis followed by Duncan's test.

Greenhouse experiment. According to the results (Fig. 2), the use of bacteria as a soil treatment was more effective to suppress the disease than those as a seed treatment. The percentage of healthy plants in the presence of strains V14, V28 and V69 as soil treatments and Phytophtora inoculums was significantly more than those of infected control plants without bacterial inoculums. Mortality in pots treated with strain CV6 and V11 was very low and the percentage of healthy plants was 85.71 and $69.39 \%$, respectively. Disease suppression by strain CV6 significantly was more than that Ridomil, whereas some strains such as V16 and V64 were not able to reduce the disease. Moreover, there was no significant difference between fresh and dry weight of plants treated with strain CV6 and non-infected control 
plants (Data not shown). However, the application of mixture of bacterial strains as soil and seed treatments on pots inoculated with the pathogen resulting in falling down the most of the plants, so that only 4.83 percent of plants showed healthy condition (Fig. 2). In other hand, by using mixture of bacterial strains, numbers of healthy plants were significantly lower than those of infected plants without bacteria.

\section{Discussion}

In current study we isolated and screened the rhizobacteria from cucumber plants with antagonistic activity against $P$. drechsleri, the causal agent of cucumber root rot. The approach provided an opportunity to select effective biocontrol strains capable of antagonizing soil-borne pathogens in the same environment where they will be used commercially (Landa et al., 1997). Moreover, isolation of bacteria from rhizosphere of the target crop is essential for successful identification of potential biocontrol agents (Williams and Asher, 1996). Use of Gould's S1 and NA media culture for isolation of bacteria, provided a very efficient tool for screening of fluorescent pseudomonads. The selectivity of Gould's S1 medium is based on an iron limitation, and high glycerol and sucrose contents. It is also based on other compounds such as sodium lauroyl sarcosine (which inhibits the growth of Gram-positive bacteria) and trimethoprim (an antibiotic limiting the growth of non-fluorescent Pseudomonas). This medium allowed a high recovery of fluorescent Pseudomonas phenotypes from soil samples (Gould et al., 1985).

In this study, the strains with high ability of root colonization were more effective in suppressing of Phytophthora root rot on cucumber plants (Figs. 1 and 2). In the most cases, strains with a higher level of root colonization caused to higher growth of plants. Growth promotion of plants can increase their resistance to disease. Moreover, in many cases, variable performance of introduced rhizobacteria has been attributed to insufficient root colonization, a process whereby the bacteria inoculated onto seed attach to the root surface, and colonize the developing root system (Weller, 1988).

It is known that in vitro assays have certain limitations in that the biocontrol efficiencies may not be equally expressed under gnotobiotic (axenic) and in vivo conditions (Inam-ul-Haq et al., 2003). However, the in vitro assays conducted in our study (pathogen inhibition ability) were used to screen and select potential biocontrol agents and subsequently test their ability to suppress Phytophthora root rot under greenhouse conditions. Correlation analyses indicate that disease incidence is significantly correlated with the inhibition activity by non-volatile compounds and
Table 3. Pearson correlations between inhibition activity, root colonisation and disease suppression by beneficial bacteria

\begin{tabular}{lccc}
\hline \hline & \multicolumn{2}{c}{ Disease suppression } \\
\cline { 2 - 4 } & & $\begin{array}{c}\text { Seed } \\
\text { treatment }\end{array}$ & $\begin{array}{c}\text { Soil } \\
\text { treatment }\end{array}$ \\
\hline Inhibition zone & Volatile & $-0.543^{* *}$ & $-0.316^{\text {ns }}$ \\
& Non-volatile & $0.406^{*}$ & $0.424^{*}$ \\
Root colonization of plants & & $0.533^{* *}$ & $0.262^{\text {ns }}$ \\
$\begin{array}{l}\text { Disease suppression by seed } \\
\text { treatment }\end{array}$ & $1^{* * *}$ & $0.892^{* *}$ \\
\hline
\end{tabular}

* and ** mean $P<0.05$ and $P<0.01$, respectively

${ }^{\text {ns }}$ means non significant difference

the degree of root colonization by the bacterial inoculants (Table 3). Our results suggest that these variations in colonization levels may be affect the beneficial activity of the bacteria.

Among the bacterial genera used in biocontrol, Pseudomonas and Bacillus species are the most widely studied (Haas and Defago, 2005; Raaijmakers et al., 2002; Whipps, 2001). The mechanisms by which they protect plants against pathogens are diverse and include competition, antibiosis, degradation of fungal pathogenicity factors, and induced systemic resistance (Fallahzadeh et al. 2009; Haas and Deffago, 2005). Correlation analyses in this study indicate that disease incidence is significantly correlated with the inhibition activity by non-volatile compounds and the degree of root colonization by the bacterial inoculants (Table 3). Our results suggest that these variations in colonization levels may be affect the beneficial activity of the bacteria. Recent studies have shown that biosurfactantproducing Pseudomonads are very effective in controlling disease caused by Oomycete pathogens, including Pythium and Phytophthora species (De Jonghe, 2006; Stanghellini et al., 1996; Stanghellini and Miller, 1997; Stanghellini et al., 2000; Nielsen et al., 2006). Biosurfactants, including rhammnolipids and cyclic lipopeptides (CLPs), disrupt the membrane integrity of Phytophthora zoospores leading to complete elimination of infectious zoospore population within minutes (de Bruinjn et al., 2007; De Jonghe, 2006; Stanghellini and Miller, 1997; de Souza et al., 2003). Only limited attempts have been made to control Phytophthora infections using Bacillus species as a biological agent. One of our promising strains identified as B. subtilis v14 that significantly suppressed the disease in greenhouse studies, but it was not as effective as Pseudomonas strains. Lee et al. (2007) screened 41 isolates of Bacillus from rhizosphere of Red pepper that two of them exhibited more than $70 \%$ of ability to reduce the severity of Phytophthora blight on Red pepper.

Introduction of PGPR strains to phyllosphere, spermo- 
sphere or rhizosphere may be moderately effective or sometimes totally ineffective under field conditions to control plant diseases (Duffy et al., 1996). Inefficacy of the strains under field conditions may be due to the variation in climatic conditions that suppress growth and survival of biocontrol agents (Guetsky et al., 2001). In addition both pathogen and biocontrol agents does not have similar ecological niche for their growth and survival. Hence the efficacy of biocontrol agents could be improved through the usage of compatible mixed inoculum of biocontrol agents which could have a consistent performance under diverse environmental conditions (Guetsky et al., 2001; Janisiewicz, 1996). For this propose we used a condition of bacterial isolates as a treatments for assessing their interaction on damping off disease. In the contrary, our study showed that the combination mixture of our biocontrol strains had a negative effect on disease incidence. It seems that interaction of isolates resulted in production of some deleterious metabolites that have a negative effect on plants. In summary, the results of this investigation are very promising for the selection of beneficial bacteria for organic and sustainable cropping systems.

\section{Acknowledgment}

We gratefully acknowledge financial support from the Islamic Azad University of Varamin-Pishva, Varamin, Iran.

\section{References}

Ahmed-Idris, H., Labuschagne, N. and Korsten, L. 2007. Screening rhizobacteria for biological control of Fusarium root and crown rot of sorghum in Ethiopia. Biol. Con. 40:97-106.

Alavi, A. and Strange, R. N. 1979. A baiting for isolating Phytophthora drechsleri, causal agent of crown rot of Cucumis species in Iran. Plant Dis. Rep. 63:1084-1086.

Alavi, A. and Strange, R. N. 1982. The relative susceptibility of some cucurbits to an Iranian isolate of Phytophthora drechsleri. Plant Pathol. 31:221-227.

Alexander, B. J. R. 1999. Studies on Biological Control of Phytophthora cactorum on Apple. Ph.D. Thesis, University of Auckland, New Zealand.

Babadoost, M. and Islam, S. Z. 2003. Fungicide seed Sreatment effects on seedling damping-off of pumpkin caused by Phytophthora capsici. Plant Dis. 87:63-68.

Bloemberg, G. V. and Lugtenberg, B. J. J. 2001. Molecular basis of plant growth promotion and biocontrol by rhizobacteria. Curr. Opin. Plant Biol. 4: 343-350.

de Bruijn, I., de Kock, M. J. D., Yand, M., de Waard, P., van Beek, T. A. and Raaijmakers, J. M. 2007. Genome-baced discovery, structure prediction and functional analysis of cyclic lipopeptide antibiotics in Pseudomonas species. Mol. Microbiol. 63:417-428. de Jonghe, H. 2006. Control of Phytophthora spp. By means of (bio) surfactants and surfactant-producing Pseudomonas spp. Ph.D. Thesis, Gent University, Belgium.

de Souza, J. T., de Boer, M., de Waard, P., van Beek, T. A. and Raaijmakers, J. M. 2003. Biochemical, genetic, and zoosporicidal properties of cyclic lipopeptide surfactants produced by Pseudomonas fluorescens. Appl. Environ. Microbiol. 69:71617172.

Duffy, B. K., Simon, A. and Weller, D. M. 1996. Combination of Trichoderma koningii with fluorescent pseudomonads for control of take-all of wheat. Phytopathology 86:188-194.

Erwin, D. C. and Ribeiro, O. K. 1996. Phytophthora capsici. in: Phytophthora Diseases Worldwide, ed. by D.C. Erwin and O.K. Ribeiro, pp. 262-268. APS Press, St. Paul, MN, USA.

Fallahzadeh-Mamaghani, V., Ahmadzadeh, M. and Sharifi, R. 2009. Screening systemic resistance-inducing fluorescent pseudomonads for control of bacterial blight of cotton caused by Xanthomonas campestris pv. malvacearum. J. Plant Pathol. 91:663-670.

Gould, W. D., Hagedron, C., Bardinelii, T. R. and Zablotowicz, R. 1985. New selective media for enumeration and recovery of fluorescent Pseudomonads from various habitats. Appl. Environ. Microbiol. 49:28-32.

Guetsky, R., Elad, Y., Shtienberg, D. and Dinoor, A. 2001. Combining biocontrol agents to reduce variability of biological control. Phytopathology 91:261-267.

Haas, D. and Defago, G. 2005. Biological control of soil-born pathogens by fluorescent Pseudomonads. Nature Rev. Microbiol. 3:307-319.

Hwang, B. K. and Kim, C. H. 1995. Phytophthora blight of pepper and its control in Korea. Plant Dis. 79:221-227.

Inam-ul-Haq, M., Javed, M., Ahmad, R. and Rehman, A. 2003. Evaluation of different strains of Pseudomonas fluorescense for the biocontrol of Fusarium wilt of chickpea. Pakistan J. Plant Pathol. 2:65-74.

Islam, S. Z. and Babadoost, M. 2002. Effect of red-light treatment of seedlings of pepper, pumpkin, and tomato on the occurrence of Phytophthora damping-off. Hort. Sci. 37:678-681.

Janisiewicz, W. J. 1996. Ecological diversity, niche overlap, and coexistence of antagonists used in developing mixtures for biocontrol of postharvest diseases of apples. Phytopathology 86:473-479.

Keel, C., Schnider, U., Maurhofer, M., Voisard, C., Laville, J., Burger, U., Wirthner, P., Haas, D. and Defago, G. 1992. Suppression of root diseases by Pseudomonas fluorescens CHAO: importance of bacterial secondary metabolite, 2,4-diacetylphoroglucinol. Mol. Plant-Microbe Interact. 5:4-13.

Kloepper, J. W., Leong, J., Teintze, M. and Schroth, M. N. 1980. Enhanced plant growth by siderophores produced by plant growth promoting rhizobacteria. Nature 268:885-886.

Kraus, J. and Loper, J. E. 1992. Lack of evidence for a role of antifungal metaoolite production by Pseudomonas fluorescense PF5 in biological control of Pythium damping-off of cucumber. Phytopathology 82:264-271.

Kreutzer, W. A., Bodine, E. W. and Durrell, L. W. 1940. Cucurbit diseases and rot of tomato fruit caused by Phytophthora cap- 
sici. Phytopathology 30:972-976.

Lamour, K. H. and Hausbeck, M. K. 2000. Mefenoxam insensitivity and the sexual stage of Phytophthora capsici in Michigan cucurbit fields. Phytopathology 90:396-400.

Lamour, K. H. and Hausbeck, M. K. 2001. Investigating the spatiotemporal genetic structure of Phytophthora capsici in Michigan. Phytopathology 91:973-980.

Landa, B. B., Hervas, A., Bethiol, W. and Jimenez-Diaz, R. M., 1997. Antagonistic activity of bacteria from the chickpea rhizosphere against Fusarium oxysporum f.sp. ciceris. Phytoparasitica 25:305-318.

Lee, K. J., Kamala-Kannan, S., Sub, H. S., Seong, C. K. and Lee, G. W. 2007. Biological control of Phytophthora blight in red pepper (Capsicum annumm L.) using Bacillus subtilis. World J. Microbiol. Biotechnol. 24:1139-1145.

McGrath, M. T. 2001. Vegetable MD online: Phytophthora blight of cucurbits. Cooperative Extension, New York State, Cornell University. Online publication.

Nielsen, C. J., Ferrin, D. M. and Stanghellini, M. E. 2006. Efficacy of biosurfactants in the management of Phytophthora capsici on pepper in recirculating hydroponic systems. Can. J. Plant Pathol. 28:450-460.

Osburn, R. M., Milner, J. L., Oplinger, E. S., Smith, R. S. and Handelsman, J. 1995. Effect of Bacillus cereus UW85 on the yield of soybean at two field sites in Wisconsin. Plant Dis. 79: 551-556.

Raaijmakers, J. M., Vlami, M. and de Souza, J. T. 2002. Antibiotic production by bacterial biocontrol agents. Antonie van leeuwenhoek. Int. J. Gen. Appl. Microbiol. 81:537-547.

Rangajaran, S., Saleena, L. M., Vasudevan, P. and Nair, S. 2003. Biological suppression of rice diseases by Pseudomonas spp. under saline soil conditions. Plant Soil 251:73-82.

Schaad, N. W., Jones, J. B. and Chun, W. 2001. Laboratory guide for identification of plant pathogenic bacteria. Third edition. APS press, MN. USA.

Sid Ahmed, A., Ezziyyani, M., Pérez-Sanchez, C. and Candela, M. E. 2003. Effect of chitin on biological control activity of Bacillus spp. and Trichoderma harzianum against root rot disease in pepper (Capsicum annuum) plants. Eur. J. Plant Pathol. 109:418-426.

Stanghellini, M. E. and Miller, R. M. 1997. Their identity and potential efficacy in the biological control zoosporic plant pathogens. Plant Dis. 81:4-12.

Stanghellini, M. E., Kim, D. H., Rasmussen, S. L. and Rorabaugh, P. A. 1996. Control of root rot of peppers caused by Phytophthora capsici with a nonionic surfactant. Plant Dis. 80:11131116.

Stanghellini, M. E., Nielsen, C. J., Kim, D. H., Rasmussen, S. L. Nda Rorabaugh, P. A. 2000. Influence of sub-versus-top-irrigation and surfactants in a recirculating system on disease incidence caused by Phytophthora spp. in potted pepper plants. Plant Dis. 84:1147-1150.

Thomshaw, L. S. 1996. Biological control of plant pathogens. Curr. Opin. Biotech. 77:343-347.

Tracey, M. T. W., Kerry, K. and Mark, J. B. 2004. Risk assessment for engineered bacteria used in biocontrol of fungal disease in agricultural crops, Plant and Soil 266:57-67.

Weller, D. M. 1988. Biological control of soil borne plant pathogens in the rhizosphere with Bacteria. Annu. Rev. Phytopathol. 20:379-407.

Whipps, J. M. 2001. Microbial interaction and biocontrol in the rhizosphere. J. Exp. Bot. 52:487-511.

Williams, G. E. and Asher, M. J. C. 1996. Selection of rhizobacteria for the control of Pythium ultimum and Aphanomyces cochlioides on sugarbeet seedlings. Crop Prot. 15:479-486. 